\title{
Soya bean Adoption: A Double-hurdle Approach for Chewaka and Gobusayo Districts of Oromia Region, Ethiopia
}

\author{
Galmesa Abebe ${ }^{*} \quad$ Jema Haji $^{2} \quad$ Workneh Kassa ${ }^{3}$ \\ 1.Bako Agricultural Research Center Oromia Agricultural Research Institutes, Bako, Ethiopia \\ 2.School of Agricultural Economics and Agribusiness,Haramaya University, Dire Dawa,Ethiopia \\ 3.College of Business and Economics, Addis Ababa University, Addis Ababa, Ethiopia
}

\begin{abstract}
Achieving national food security and diversifying export earnings from agricultural products is one of the major challenges currently facing developing countries like Ethiopia. Pulse crops in general and soya bean in particular play great role in improving households' food security, increasing income for smallholder farmers. Despite the high production potential and the economic importance of the crop, adoption and dissemination of improved soya bean varieties is constrained by various factors. Therefore, this study aimed at identifying determinants of adoption and intensity of adoption of improved soya bean varieties. The study was based on cross sectional data collected from 146 randomly selected soya bean producing farmers. Descriptive and econometric analyses were used to analyze data. The result showed that sex of household, education level, training, distance to nearest market, participation on off-farm activities and TLU affected the probability of adoption while education, farm experience, training, distance to nearest market and TLU affected the intensity adoption of improved soya bean varieties significantly. This study suggests that the high importance of institutional and government support in the areas of education, training, infrastructural development (especially roads). Therefore, policy and development interventions should give emphasis to the improvement of such institutional support system and decrease gender disparities in access to such institutions so as to achieve the adoption practice which increases production and productivity of small scale farmers.
\end{abstract}

Keywords: Adoption, intensity of adoption, soya bean, double hurdle

DOI: $10.7176 /$ JNSR/9-20-06

Publication date:October $31^{\text {st }} 2019$

\section{Introduction}

Agriculture is a dominant sector of Ethiopian economy which makes a lion share contribution to the Gross Domestic Product, employment and foreign exchange earnings. Agriculture is still believed to remain a sector that plays an important role in stimulating the overall economic development of the country in the years to come. This would be realized if and only if strenuous efforts are made by the government and other concerned stakeholders including farmers to increase agricultural production and productivity (CSA, 2016).

In many developing countries including Ethiopia, agriculture plays a vibrant role in promoting economic growth and development. The importance of agriculture in Ethiopia is evidenced by its share in GDP (43\%), its employment generation (80\%), share of export (70\%) and providing about $70 \%$ raw material for the industries in the country in 2012/13(UNDP, 2013). Furthermore, 90\% of the poor earn their livelihood from this sector (Yu et $a l$,. 2011). Thus, it is not surprising that policy action in Ethiopia is largely based on influencing the dynamism of the agricultural sector.

The importance of agricultural technology adoption in ending poverty and food insecurity has been well discussed by Besley and Case (1993); Doss and Morris (2001); Mendola (2007); and Becerril and Abdulai (2009). According to Ajayi et al.(2003), Gemeda et al. (2001) and Morris et al. (1999) in developing countries, improving the livelihoods of rural farm households via agricultural productivity would remain a mere wish if agricultural technology adoption rate is low. Hence, there is a need to adopt the proven agricultural technologies so as to increase production as well as productivity and thereby the living condition of the rural poor. Furthermore, for developing countries, the best way to catch developed countries is through agricultural technology diffusion and adoption (Foster and Rosenzweig, 2010). Additionally, in Nigeria, Uaiene et al. (2009) have had acclaimed as if production and productivity would likely to slow down and rural poverty would prevail more if attention is not given to the use and adoption of agricultural technologies. Datt and Ravallion (1996) and Hossain (1992) have purported that, since the need of the rapidly growing population could not be meet by expanding the area under cultivation, developing, employing and disseminating yield increasing agricultural technologies is imperative. In their finding, Ibrahim et al. (2012) purport about the direct effect of technology adoption on the farmer's income resulting from higher yields and prices. In line with this thought, according to Besley and Case (1993) purport that; adoption of HYV has long been taken as a solution to heighten agricultural income and diversification.

Soya bean is a multipurpose crop, which can be used for a variety of purposes including preparation of different kinds of soya bean foods, animal feed, soy milk, raw material for the processing industry, and it counter effects depletion of plant nutrients in the soil resulting from continuous mono-cropping of cereals, especially maize 
and sorghum, thereby contributing to increasing soil fertility (Hailegiorgis, 2010). Producing and consuming more soya bean would improve food insecurity and malnutrition as soya bean provides a nutritious combination of both calorie and protein intake. It is the most nutritionally rich crop, as its dry seed contains the highest protein and oil content among grain legumes ( 40 to $42 \%$ protein) with a good balance of the essential amino acids and has $18-20 \%$ oil on a dry seed weight basis (FAO 2010).

Despite the significance of soya bean to address food security and malnutrition problems little emphasis has been given to production, supply and export of this important commodity. This study therefore conducted to examine the determinants of adoption and intensity of adoption of improved soya bean varieties with a purpose of generating information that help understand and evaluate the key challenges to the adoption of improved soya bean in the study areas which will enhance informed decision making to improve adoption of soya bean, its production and productivity in the study areas.

\section{Objectives of the Study}

The general objective of the study was to analyze the determinants of adoption and intensity of adoption of improved soya bean varieties. The specific objectives of the study were:

1. To identify factors affecting adoption of improved soya bean varieties in the study areas

2. To identify factors affecting intensity of adoption of improved soya bean varieties in the study areas.

\section{Statement of the Problem}

Adoption of technological innovations in agriculture has attracted considerable attention among development economists because the majority of the population of less developed countries derives their livelihood from agricultural production and a new technology, which apparently offers opportunities to increase production and productivity (Feder et al., 1985).Agriculture progresses technologically as farmers adopt innovations. The extent to which farmers adopt available innovations and the speed by which they do so determines the impact of innovations in terms of productivity growth (Diederen et al., 2003).

Adoption of agricultural innovations in developing countries attracts considerable attention because it can provide the basis for increasing production and income. Small-scale farmers' decision to adopt or reject agricultural technologies depends on their objectives and constraints as well as costs and benefits accruing to it (Million and Belay, 2004). Hence, farmers will adopt only technologies that suit their needs.

According to Sunding and David (2000), measures of adoption may indicate both the timing and extent of new technology utilization by individuals. Adoption behavior may be depicted by more than one variable. It may be depicted by a discrete choice, whether or not to utilize an innovation, or by a continuous variable that indicates to what extent a divisible innovation is used. Adoption at the farm level describes the realization of a farmer's decision to implement a new technology. On the other hand, aggregate adoption is the process by which a new technology spreads or diffuses through a region. Therefore a distinction exists between adoption at the individual farm level and within a targeted region. If an innovation is modified periodically, however, the equilibrium level of adoption will not be achieved. This situation requires the use of econometric procedures that can capture both the rate and the process of adoption (Degu et al., 2000).

The major challenges facing most of developing countries such as Ethiopia is improving rural livelihoods as well as food security and to stimulate underlying food system development. There is an ever-increasing concern that it is becoming more and more difficult to achieve and sustain the needed increase in agricultural production based on intensification, because there are limited opportunities for area expansion (Kebede et al., 1990). Hence, the solution to food insecurity problem would depend on measures which help to increase yield through intensification. In Ethiopia, adoption of improved agricultural technologies has been a long term concern of agricultural experts, policy makers, and agricultural research and many others linked to the sector. However, evidence indicates that adoption rate of modern agricultural technologies in the country is very low (Kebede et al., 1990).

Improved soya bean varieties have been generated and promoted for many years in the study areas. N2Africa project and Bako Agricultural Research Center are doing their best efforts which aimed at improving soya bean productivity in the study areas. Despite such an intervention the adoption of improved soya bean varieties is still very low and there is also variation among farmers in their intensity of adoption. Moreover, there is no empirical information on the various factors determining adoption, intensity of adoption of improved soya bean varieties in the study areas. Therefore, this study was proposed to identify the determinants of adoption and intensity of adoption of improved soya bean varieties to fill the existing knowledge gap

\section{Methodology \\ Description of the Study Area}

Chewaka is located in Buno Bedele zone, Oromia Regional state about 570 kilometers southwest of Addis Ababa (the capital city of the country). It covers a total area of $342.167 \mathrm{~km}^{2}$. It is situated in lowland areas of Dhidhessa 
valley, which lies below 1500m above sea level. The area is found between Dabena and Dhidhessa rivers. Dhidhessa River bounds the district from east to north and at the same time it is the boundary between Illubabor and East Wollega zone. On the other hand Dabena River bounds the area from west to north which joins Dhidhessa and finally leads to Blue Nile.

GobuSayo district is located in East Wellega Zone of Oromia region $265 \mathrm{~km}$ west of Addis Ababa (the capital city of the country). Its altitude is in the range of 1556-1680 meter above sea level. The capital town of Gobu Seyo (Ano) is located 65 K.M to East from Nekemte, the capital town of East Wellega Zone. The district consists of 9 Kebele Administrations.

\section{Sampling Procedure}

A three stage sampling technique was employed to select sample respondents. In the first stage, Chewaka and Gobusayo districts were purposively selected for this study, due to the fact that improved soya bean varieties was widely popularized by Bakko Agricultural Research Center (BARC) and N2 Africa project in the study areas. In the second stage, five Kebeles were randomly selected. Three Kebeles from Chewaka district and two Kebeles from Gobusayo district were selected for this study. Households in sample kebeles were stratified into producers and non-producers of soya bean and representative samples were selected from producers of soya bean. The sample size was determined by using a formula developed by Cochran's (1977):

$$
n=\frac{Z^{2} p q}{e^{2}}
$$

Where $\mathrm{n}$ is the sample size for the study, $\mathrm{Z}$ is the selected critical value of desired confidence level (1.96), $\mathrm{p}$ is the estimated proportion of an attribute that is present in the population while $q=1-p$ and $e$ is the desired level of precision

Data Analysis.

In this study, both descriptive statistics and econometric model were used to analyze the data.

\section{Descriptive statistics}

Descriptive statistics such as mean, standard deviation, frequencies distribution, and percentages were used to have a clear picture of the characteristics of sample units. Chi-square test and t-tests were also used to compare adopters and non-adopters in terms of explanatory variables.

\section{Econometric model}

The Cragg's double hurdle model regression applied to assist in estimating the probability of adoption and intensity of adoption of improved soya bean varieties. According to Cragg's model, a farmer faces two hurdles while deciding on soya bean cultivation. The first is to decide whether to cultivate soya bean. The second hurdle is related to the level of adoption, or how much land or capital to allocate to soya bean production. The most important underlying assumption of the model is that these two decisions are made in two different stages. At the beginning of a cropping season a farmer may decide to cultivate soya bean without making exact plans about the quantity of land. Many factors can influence a farmer's decision afterwards, i.e., price and availability of inputs, potential to cultivate competing crops, information about production technology, etc.

The first stage of Cragg's model is a probit model to identify the determinants of adoption, and the second stage is a truncated model for identifying the determinants of the intensity of adoption (Cragg, 1971). Let $d_{i}{ }^{*}$ is the latent variable describing a farm's decision to adopt, $y_{i}{ }^{*}$ is the latent variable describing its decision on the level of adoption, and $d_{i}$ and $y_{i}$ are their observed counterparts, respectively. Based on the specification by Cragg (1971) and Moffatt (2005), the two hurdles for a farmer can be written as:

$d_{i}{ }^{*}=\alpha z_{i}+v_{i}$

$y_{i}^{*}=\beta \boldsymbol{x}_{i}+\varepsilon_{i}$

Where

$$
d_{i}=\left\{\begin{array}{l}
1, \text { if } d_{i} *>0 \\
0, \text { if } d_{i} * \leq 0
\end{array} \text { and } y_{i}=\left\{\begin{array}{l}
y_{i}^{*}, \text { if } y_{i}^{*}>0 \text { and } d_{i} *>0 \\
0, \text { if } \text { otherwise }
\end{array}\right.\right.
$$

Where $\boldsymbol{z}_{i}$ is the vector of variables explaining whether a farmer adopts improved soya bean varieties, $\boldsymbol{x}_{i}$ is a vector of variables explaining level of adoption, and $v_{i}$ and $\varepsilon_{i}$ are the error terms. 
The dependent variable in the first stage is the farmer's adoption decision. This variable is binary in nature, taking numeric value 1 for adopters, and 0 for non-adopters. In the second stage, the dependent variable is area of improved soya bean varieties cultivated in hectare. In the double-hurdle model, both hurdles have equations associated with them, incorporating the effects of farmer's characteristics and circumstances. Such explanatory variables may appear in both equations or in either of them (Teklewold et al., 2006). According to Carroll et al (2005), equations 1 and 2 are assumed to be independent, and therefore the error terms are randomly and independently distributed, $v_{i} \sim N(0,1)$ and $\varepsilon_{i} \sim N\left(0, \sigma_{\varepsilon}{ }^{2}\right)$.

The log-likelihood function for the double hurdle model is:

$\log L=\sum \ln \left[1-\Phi\left(\alpha Z_{i}{ }^{\prime}\left(\frac{\beta X_{i}}{\sigma}\right)\right)+\sum \ln \left[\Phi\left(\alpha Z_{i}\right) \frac{1}{\sigma} \phi\left(\frac{Y_{i}-\beta X_{i}}{\sigma}\right)\right]\right.$

Where $\Phi$ and $\phi$ are the standard normal cumulative distribution function and density function, respectively. The log-likelihood function is estimated using the maximum likelihood estimation (MLE) technique.

The double-hurdle model is reduced to the Tobit model when the probit mechanism $\left(d_{i}{ }^{*}>0\right)$ is absent in Equation 2. This can also be seen in the log-likelihood function presented in Equation 3, when $\Phi\left(z_{i} \alpha\right)=1$. The Tobit model arises if $\alpha=\beta / \sigma$ and $x=z$ (Martinez-Espineira, 2006). Absence of the probit mechanism implies that the decision about adoption and level of adoption are made simultaneously. We also develop a Tobit model and do standard likelihood ratios test between the Tobit and double-hurdle model to know how these decisions are made. Following Gujarati (2003), the Tobit model for our specific case can be written as:

$y_{i}=\left\{\begin{array}{l}y_{i}^{*} \text { if land allocated for soybean }>0 \\ \text { o otherwise }\end{array}\right.$

Where, $\beta_{0} \ldots, \beta_{k}$ are the unknown parameters to be estimated and $\boldsymbol{x}_{1 i} \ldots \boldsymbol{x}_{k i}$ are the same set of explanatory variables used in the second stage of the Cragg model. Using MLE, the Tobit model is estimated. According to Maddala (1992), the likelihood function for the Tobit model can be written as

$$
L=\prod_{V_{i}>0} \frac{1}{\sigma} f\left(\frac{y i-\beta x_{i}}{\sigma}\right) \prod_{V_{i}<0} F\left(-\frac{\beta X_{I}}{\sigma}\right)
$$

Through maximizing the function with respect to $\beta$ and $\sigma$, we get the MLE estimates of these parameters. As the Tobit model is nested in the Cragg model, it is possible to compare these two models through a standard likelihood ratio test when the determinants in both hurdles are the same (Buraimo et al, 2010). The test statistics can be computed as in Greene (2000):

$\Gamma=-2\left[\ln L_{T}-\left(\ln L_{P}+\ln L_{T R}\right)\right] \sim \chi_{k}^{2}$,

Where $L_{T}, L_{P}$, and $L_{T R}$ are log-likelihoods of the Tobit, probit, and truncated regression models, respectively. Rejection of the null hypothesis $\left(\Gamma>\chi_{k}^{2}\right)$ argues for superiority of the double-hurdle model over the Tobit model and establishes that the decisions about adoption and level adoption are made in two different stages.

\section{Definitions of Variables and Hypothesis \\ Dependent variables}

Adoption decision: The dependent variable for probit model takes a dichotomous value depending on the farmers' decision either to adopt (at least one) or not to adopt any of the improved soya bean varieties.

Intensity of adoption: The dependent variable for truncated regression model would have a continuous value which is the intensity of use of the technology. In this case, it indicates the proportion of area cultivated under improved soya bean varieties in hectare. Adopters are farmers who produce either of Dedessa, Katta, Jalale and Ethio-Yugoslavia varieties. Non-adopters are farmers who did not produce those improved varieties during the production year.

\section{Independent variables}

Adoption literature provides a long list of factors that may influence the adoption of agricultural technologies. Generally, farmers' decision to use improved agricultural technologies and the intensity of the use in a given period of time are hypothesized to be influenced by a combined effect of various factors such as household characteristics, socioeconomic and physical environments in which farmers operate. Based on the previous studies conducted on the adoption of improved crop technologies and the experience of the farming system of the study areas, the following listed explanatory variables in the table were selected for this study. 
Sex of the household head: This is a dummy independent variable indicating sex of the household head. It was represented by 1 for males and 0 , otherwise. The gender difference is found to be one of the factors influencing adoption of new technologies. Female headed households are not efficient and able to adopt new technology as compared to their male counterpart (Yemane, 2014, Samuel et al 2017). Therefore, it is hypothesized that male farmers are more likely to adopt new technologies.

Age of the household head: Age is a continuous variable and is one of the factors that affect adoption, intensity of adoption and speed of adoption in one of the several ways. The direction of influence is not, however, very clear and there are always mixed results from empirical analysis. Older farmers may have more experience, resource, or authority that would allow them more possibilities for trying new technologies. On the other hand, it may be that young farmers are more likely to adopt new technologies, because they may have more schooling than older farmers and have been exposed to new ideas and hence more risk takers (Assefa and Gezahegn, 2010). Hence, age of the household head may have positive or negative effect on the adoption and intensity of adoption of improved soya bean varieties.

Education level of the household head: It is a continuous variable measured in terms of the level of education a farmer attended. It is expected that the more years an individual is exposed to education, the more open he/she would be to new ideas. Educated farmers may also be more aware of the benefits of modern technologies and may have a greater ability to learn new information hence easily adopt new technologies. Hence, educational level of the household head has a positive effect on the status, intensity and speed of technology adoption (Hassen et al., 2012; Afework and Lemma, 2015). Education thus was expected to have a positive effect on the decision to adopt and intensity of adoption of improved soya bean varieties.

Contact with extension agents: It is a continuous variable measured in terms of the frequency of contact between the extension agent and the farmers is hypothesized to be the potential force, which accelerates the effective dissemination of adequate agricultural information to the farmers, thereby enhancing farmers' decision to adopt new crop technologies. According to Yemane (2014) contact with extension agents has positively influenced the adoption of improved upland rice varieties. A similar study of Hassen et al., (2012) indicated that, more contacts with extension agents will increase farmers' adoption of technologies. It was hypothesized that contact with extension workers will increase a farmer's likelihood of adoption and intensity of adoption of improved soya bean varieties.

Farm size: It is a continuous variable measured in hectares. Farm size is an indicator of wealth and social status and influence within a community. This means that farmers who have relatively large farm size will be more initiated to adopt new technologies and the reverse is true for small size farmers. The land holding size returned a positive and significant relationship with adoption of new technology (Yenealem et al., 2013; Solomon and Bekele, 2010). Therefore, it is expected to be positively associated with the decision to adopt and intensity of adoption improved soya bean varieties.

Area allocated under improved soya bean: It is a continuous variable measured in hectares. Therefore, it is expected to be positively associated with the intensity of adoption improved soya bean varieties.

Participation in training: Training is one of the means by which farmers acquire new knowledge and skill. It is a dummy variable which have a value of 1 if the famer had been participated in training at least once in the last three years and 0, otherwise. Farmers who participated on training, their probability of adoption and intensity of adoption of new technologies increase (Wuletaw and Daniel, 2015). Hence, participation in training is expected to positively influence adoption and intensity of adoption of improved soya bean varieties.

Access to credit: It is a dummy variable that takes a value of 1 if households have access to credit and 0 , otherwise. Farmers who have access to credit may overcome their financial constraints and therefore buy inputs. The credit availability positively affects the adoption of improved technologies (Tiamiyu et al., 2014; Leake and Adam, 2015). Therefore, it is expected that access to credit will increase the probability of adoption and intensity of adoption of improved soya bean varieties.

Livestock holding: It is a continuous variable measured in TLU. A household with large livestock holding can obtain more cash income from the sales of animal products. This income in turn helps smallholder farmers to purchase farm inputs. Leake and Adam (2015) reported that being owner of more livestock increases the level of adoption of improved agricultural technology. Therefore, livestock ownership is hypothesized to be positively related to the adoption and intensity of adoption of improved soya bean varieties.

Family size: It is a continuous variable measured in terms of adult equivalent of persons living together in the household. Adoption of soya bean requires adequate labor supply to carry out the production processes. It is obvious that large families may have adequate labor that would enhance the adoption of technologies. The labor availability is positively related with the adoption of improved new technologies (Hassen et al., 2012; Debelo 2015). Hence, it is hypothesized that availability of labor has positively influenced the adoption and intensity of adoption of improved soya bean varieties.

Market distance: It is a continuous variable measured in kilometers. Market distance is one of the determining factors in the adoption of technology. Better access to the market can influence the use of output and input markets, 
and the availability of information. It is expected that farmers living near the market would easily access market for their farm produce hence readily adopt and intensively use new technology (Afework and Lemma 2015; Hassen et al., 2012). Therefore, it is hypothesized that market distance is inversely related to adoption and intensity adoption of soya bean improved soya bean varieties.

Off-farm activity: It is treated as a dummy variable taking the value of 1 if a household head participated in non/off-farm income generating activities and 0, otherwise. The households engaged in non/off-farm activities are better endowed with additional income to purchase inputs. The study by Olalekan and Simeon (2015) indicated that participation in off farm income activities has a positive influence on the adoption new technology. Therefore, it is expected that the participation in non/off-farm income is positively related to adoption and intensity of adoption of improved soya bean varieties.

Farm experience: It is a continuous variable measured in years of soya bean production. It is expected that farmers who have adequate farm experience more likely to adopt new technologies than less experienced farmers. Aman and Tewodros (2016) indicated that farm experience affect adoption and intensity adoption of improved varieties positively. Therefore, it is expected that the farm experience is positively related to adoption and intensity of adoption of improved soya bean varieties.

Table 1: Summary of independent variables, their definitions and expected effect

Dependent variables

1. Adoption of improved soya bean varieties

Dummy (1.Yes 0.No)

2. Proportion of area under improved soya bean varieties Continuous (hectare)

\begin{tabular}{|c|c|c|c|}
\hline Independent Variables & Definitions of variables & Unit of measurement & $\begin{array}{l}\text { Expected } \\
\text { sign }\end{array}$ \\
\hline District & District of study areas & $\begin{array}{l}\text { Dummy } \\
\text { 1.Chewaka } \\
\text { 0.Gobusayo }\end{array}$ & $+/-$ \\
\hline Age & Age of household head & Years & $+/-$ \\
\hline Sex & Sex of the household head & 1.Male 0.Female & + \\
\hline Family size & Number of persons per household & No & + \\
\hline Marital statues & Marital status of household heads & $\begin{array}{l}\text { 0. Married } \\
\text { 1.Divorced } \\
\text { 2.Widowed } \\
\text { 3.Single }\end{array}$ & $+/-$ \\
\hline Education & Formal education level of household head & Grade attended & + \\
\hline off farm & participation on off/ non-farm activities & 1.Yes 2.No & + \\
\hline Farming experience & $\begin{array}{l}\text { Soya bean farming experience of the } \\
\text { household head }\end{array}$ & Years & + \\
\hline Training & $\begin{array}{l}\text { Participation on training of soya bean } \\
\text { production }\end{array}$ & 1. Yes 0 . No & + \\
\hline Livestock & Number of livestock owned & TLU & + \\
\hline $\begin{array}{l}\text { Distance to market } \\
\text { center }\end{array}$ & $\begin{array}{l}\text { Distance of farmers house from nearby } \\
\text { market }\end{array}$ & Hour & - \\
\hline Credit & Use of cash credit in maize framing & $1=$ Yes $0=$ No & + \\
\hline Farm size & $\begin{array}{l}\text { Total land holding size of the household } \\
\text { head }\end{array}$ & Hectares & + \\
\hline Extension & Contact with extension agents & No & + \\
\hline
\end{tabular}

\section{Results and Discussion}

The descriptive analysis made use of tools such as mean, percentages, standard deviation and frequency. Econometric analysis was used to identify the determinants of adaption of improved of varieties. The statistical significance of the variables was tested using chi-square $\left(\chi^{2}\right)$ and t-test statistics.

\section{Descriptive Statistics}

The sample size handled during the survey was 146. Out of the total interviewed soya bean producers 94 (64.38\%) were from Chewaka district and the remaining $52(35.62 \%)$ were from Gobusayo district. Among the sample respondents from chewaka district, $74(78.72 \%)$ were male headed and the remaining $20(21.28 \%)$ were female headed while in Gobusayo 47 (90.38\%) and $5(9.62 \%)$ were male and female headed producers, respectively. The chi-square test of sex distribution between the adopters and non-adopters was found to be insignificant. Out of the total respondents, $97.26 \%, 1.37 \%$ and $1.37 \%$ were married, single and widowed respectively. The chi-square test of marital status between the adopters and non-adopters was found to be insignificant. 
Table 2: Chi- square test result output

\begin{tabular}{lllllllll}
\hline Variables & & \multicolumn{2}{c}{ Adopters $(\mathrm{N}=48)$} & \multicolumn{2}{c}{ Non adopters(N=98) } & \multicolumn{3}{c}{ Total $(\mathrm{N}=146)$} \\
& & No & $\%$ & No & $\%$ & $x^{2}$-test & No & $(\%)$ \\
\hline Sex & Male & 41 & 85.4 & 80 & 81.6 & 0.33 & 121 & 78.7 \\
& Female & 7 & 14.6 & 18 & 18.4 & & 25 & 21.3 \\
Marital & Married & 47 & 97.9 & 95 & 96.9 & 1.25 & 142 & 97.3 \\
status & Single & 1 & 2.1 & 1 & 1 & & 2 & 1.4 \\
& Widowed & 0 & 0 & 2 & 2 & & 2 & 1.4 \\
\multirow{3}{*}{ Off farm } & Yes & 9 & 18.75 & 13 & 13.27 & 0.76 & 22 & 15.07 \\
& No & 39 & 81.25 & 83 & 86.73 & & 124 & 84.93 \\
credit & Yes & 39 & 81.25 & 38 & 40.43 & $23.32 * * *$ & 77 & 52.74 \\
& No & 9 & 18.75 & 60 & 59.57 & & 69 & 47.26 \\
\hline
\end{tabular}

Participation on off farm can affect the decision to adopt new technologies. This is particularly true if the adoption of the new technology would require a minimum investment in purchased inputs. Most of the farmers interviewed reported that they didn't participate on off/non-farm because of poor infrastructure development in the area. About $18.75 \%$ of adopters and $13.27 \%$ of non-adopters participate on off farm while about $81.25 \%$ of adopters and $86.73 \%$ of non-adopters did not participate on off farm activities. The $x^{2}$ test of off farm participation between adopters and non-adopters was found to be insignificant. That means there is no difference between adopters and non-adopter in off farm participation.

Credit is an important institutional service to finance poor farmers who cannot purchase input from own savings especially at early stage of adoption. As presented in table 11 , about $81.25 \%$ and $40.43 \%$ adopters and non-adapters access credit respectively while about $18.75 \%$ and $59.57 \%$ does not access credit. The result of $x^{2}$ test revealed that there is difference in access to credit between adopters and non-adopters farmers at $1 \%$ level of significance

The average age of the adopters was 40.17 years and while it is about 38.55 years for non-adopters. The ttest of age between adopters and non-adopters was found to be insignificant. That means there is no statistical mean difference between adopters and non-adopters in terms of age

Family size is one of the variables that characterize farm households. The average family size of the adopters was 2.83 people and while it is about 2.66 persons for non-adopters. The t-test of family size between adopters and non-adopters was found to be insignificant

Table 3: t-test result output

\begin{tabular}{llllll}
\hline Variables & Adopter & $(\mathrm{N}=48)$ & \multicolumn{2}{l}{ Non-adopters $(\mathrm{N}=98)$} & \\
& mean & Std & Mean & Std & t-test \\
\hline Age & 40.17 & 1.91 & 38.55 & 1.22 & -0.73 \\
Family size & 2.83 & 0.24 & 2.66 & 0.13 & -0.70 \\
Farm experience & 10.44 & 1.77 & 8.58 & 1.20 & -0.40 \\
Education level & 6.29 & 0.43 & 3.20 & 0.33 & $-5.46^{* * *}$ \\
Livestock holding(TLU) & 5.17 & 0.97 & 4.13 & 0.47 & -1.0937 \\
Total land holding & 2 & 0.14 & 2.20 & 0.16 & 0.88 \\
Total cultivated land & 1.84 & 0.12 & 1.97 & 0.13 & 0.62 \\
Extension contact & 10.56 & 2.87 & 1.7 & 0.56 & $-4.11^{* * *}$ \\
Distance to nearest market & 0.24 & 0.02 & 0.97 & 0.08 & $5.81^{* * *}$ \\
\hline
\end{tabular}

Experience in soya bean production is taken to be the number of years that an individual was continuously engaged in soya bean production. The average years of soya bean production experience for the adopters was about 10.44 years and 8.58 years for non-adopters with standard deviation of 1.77 and 1.2 respectively. A producer with better experience in soya bean production is expected to adopt new technologies than less experienced. The t-test of farm experience between adopters and non-adopters was insignificant

Education can influence productivity of producers and adoption of newly introduced technologies and innovations. Hence, literate producers are expected to be in a better position to get and use information which contributes to improve their soya bean production practices. According to the survey results, on average adopters have about 6 grades of formal educations while non-adopters have 3 . The t-test result indicates that education level of household was found to be significant between adopters and non-adopters at $1 \%$ level of significance. That means adopters have higher level of education compared to non-adopters (Table 3).

Farm animals have an important role in rural economy. They are source of draught power, food, such as, milk and meat, cash, animal dung for organic fertilizer and fuel and means of transport. The districts where known by livestock production as major occupation. Livestock holding size is also one of the indicators of wealth status of the households in the study areas. Livestock is kept both for generating income and traction power. As it confirmed in many studies, farmers who have better livestock ownership status are likely to adopt improved agricultural 
technologies because livestock can provide cash through sales of products which enables farmers to purchase different agricultural inputs like seeds and used as traction power.

The livestock species found in the study areas are cows, oxen, bulls, heifers, calves, sheep, goat, donkey, mule and poultry. To help the standardization of the analysis, the livestock number was converted to tropical livestock unit (TLU).The conversion factors used were based on Storck et al., (1991). The average livestock ownership of adopters was 5.17 and 4.13 TLU for the non-adopters. The t-test of livestock holding between adopters and non-adopters was found to be insignificant. That means there is no statistical mean difference between adopters and non-adopters in terms of livestock holding.

The average total land holding, total cultivable land and land allocated for improved soya bean for adopters is $2.00,1.84$ and 0.25 hectares respectively while it is $2.2,1.97$, and 0 hectares for non-adopters. The t-test of total land holding and total cultivable land between adopters and non-adopters was found to be insignificant. That means there is no statistical mean difference between adopters and non-adopters in terms of total land holding and total cultivable land but the t-test of land allocated for improved soya bean between adopters and non-adopters was found to be significant at 1\% level of significance indicating that there is statistical mean difference between adopters and non-adopters in terms of land allocated for improved soya bean varieties.

Frequency of extension contact refers to the number of contacts per year that the respondent made with extension agents. The effort to disseminate new agricultural technologies is within the field of communication between the change agent (extension agent) and the farmers at the grass root level. Here, the frequency of contact between the extension agent and the farmers is hypothesized to be the potential force which accelerates the effective dissemination of adequate agricultural information to the farmers, thereby enhancing farmers' decision to adopt new technologies. The mean extension contact for adopters and non-adopters was 10.56 and 1.7 respectively. The t-test of extension contact between adopters and non-adopters is significant at $1 \%$ level of significance indicating that there is statistical mean difference between adopters and non-adopters in terms of frequency of extension contact

The time taken to travel from home to the nearest soya bean market place where farmers sell their product (soya bean), are presented in table 12. Adopters and non-adopters travel on average 0.24 and 0.97 hour respectively to reach nearest market. The t-test of distance to nearest market between adopters and non-adopters is significant at $1 \%$ level of significance indicating that non-adopters travel more hours to reach nearest market than adopters.

\section{Econometric result}

Selected explanatory variables were used to estimate the probit regression model to analyze the determinants of households' adoption on soya bean varieties. A truncated regression model was used to estimate intensity of adoption of improved soya bean varieties.

Table 4. Parameter estimates of a double hurdle model for factors affecting adoption and intensity of adoption of improved soya bean varieties.

\begin{tabular}{|c|c|c|c|c|c|c|c|c|}
\hline \multirow[t]{2}{*}{ Variables } & \multicolumn{4}{|c|}{ Probit regression } & \multicolumn{4}{|c|}{ Truncated regression } \\
\hline & Coef. & $\begin{array}{l}\text { Std. } \\
\text { Err. }\end{array}$ & $\begin{array}{l}\text { Marginal } \\
\text { Effect }\end{array}$ & $\mathrm{P}>\mathrm{Z}$ & Coef. & Std. Err. & $\begin{array}{l}\text { Marginal } \\
\text { Effect }\end{array}$ & $\mathrm{P}>\mathrm{Z}$ \\
\hline Sex & 0.921 & 0.551 & 0.040 & 0.095 & 0.262 & 0.216 & 0.262 & 0.226 \\
\hline Age & -0.063 & 0.040 & -0.050 & 0.118 & -0.016 & 0.015 & -0.016 & 0.281 \\
\hline Education & 0.301 & 0.076 & 0.024 & 0.000 & 0.112 & 0.025 & 0.112 & 0.000 \\
\hline Farm experience & 0.066 & 0.044 & 0.005 & 0.130 & 0.074 & 0.109 & 0.074 & 0.07 \\
\hline Family size & 0.080 & 0.146 & 0.008 & 0.582 & -0.042 & 0.054 & -0.042 & 0.449 \\
\hline Total land holding & 0.176 & 0.150 & 0.012 & 0.239 & 0.044 & 0.066 & 0.044 & 0.508 \\
\hline $\begin{array}{l}\text { Frequency of } \\
\text { extension contact }\end{array}$ & 0.020 & 0.017 & 0.026 & 0.225 & 0.006 & 0.004 & 0.006 & 0.154 \\
\hline Training & 1.962 & 0.436 & 0.284 & 0.000 & 0.759 & 0.160 & 0.759 & 0.000 \\
\hline Access to market & -0.399 & 0.496 & -0.036 & 0.421 & -0.165 & 0.185 & -0.165 & 0.376 \\
\hline Distance to market & -3.509 & 0.809 & -0.274 & 0.000 & -1.538 & 0.314 & -1.538 & 0.000 \\
\hline Off farm & 1.041 & 0.569 & 0.042 & 0.068 & -0.330 & 0.207 & -0.330 & 0.113 \\
\hline Access to credit & 0.296 & 0.373 & 0.004 & 0.427 & 0.163 & 0.155 & 0.163 & 0.294 \\
\hline TLU & 0.046 & 0.026 & 0.003 & 0.076 & 0.110 & .0101 & 0.110 & 0.027 \\
\hline \multirow{3}{*}{$\begin{array}{c}\text { cons } \\
\text { /sigma }\end{array}$} & -0.4037 & 1.764 & & 0.819 & 0.158 & 0.632 & 0.158 & 0.803 \\
\hline & & & & & 0.613 & .0701 & 0.613 & .4741788 \\
\hline & \multicolumn{4}{|c|}{$\begin{array}{l}\text { Number of obs }=146 \\
\text { LR chi2 }(13)=113.16 \\
\text { Prob }>\text { chi2 }=0.0000 \\
\text { Pseudo R2 }=0.6128 \\
\text { Log likelihood }=-35.755491\end{array}$} & \multicolumn{4}{|c|}{$\begin{array}{l}\text { Limit: lower }=0 \quad \text { Number of obs }=48 \\
\text { upper }=+ \text { inf } \\
\text { Log likelihood }=47.154961 \quad \text { Prob }>\text { chi } 2= \\
0.0295\end{array}$} \\
\hline
\end{tabular}


Sex of household head (Sex): Sex of a house hold head is one of the determinants of improved soya bean adoption. As the probit model indicates sex of house hold head had positive and significant influence on the adoption of improved soya bean production technology at $10 \%$ significance level. This shows that being male headed households have better access to information on improved soya bean production technologies and are more likely to adopt new varieties than female headed households and also increase their soya bean production. Yenealem (2013) the binary logit model results revealed that the adoption of improved maize variety is biased by gender, where female headed households adopt the improved varieties less.

Education (EDU): Education level of the household head, which is one of the important indicators of human capital, has a positive and significant effect on adoption and intensity of improved soya bean varieties at $1 \%$ level of significance, implying that the likelihood of adoption and intensity of adoption increases with farmer's formal education level. Each additional year of education of the household head increases the probability adoption and the proportion of land allocated for improved soya bean varieties by $4 \%$ and $11.2 \%$ respectively. This is consistent with the research results of Hassen et al. (2012), Moti et al. (2013) and Afework and Lemma (2015) who stated that education, affect adoption of improved technologies positively.

Training (TRAINING): Training was positively related to adoption and intensity of adoption of improved soya bean varieties at $1 \%$ level of significance. The result of probit regression indicate that as compared to farmers who participated on soya bean training, those farmers who did not participated on soya bean training their probability of adoption of improved soya bean varieties decrease by $28.4 \%$. The result of truncated regression indicate that households who participated on training are more likely to devote significant amount of land to improved soya bean varieties than households who did not participated on training of improved soya bean varieties. As compared to households who did not participated on training, the intensity of adoption of improved soya bean increases by $75.9 \%$ for households who participated on training. This is in line with previous studies by Wuletaw and Daniel (2015) who found that training influence adoption and intensity of adoption of new technology positively. Wuletaw and Daniel (2015) training affect adoption and intensity of adoption malt-barley technology in North Gondar positively.

Distance to nearest market (DISTMARK): Distance to market center has a negative and significant relationship with probability of adoption and intensity of adoption of improved soya bean varieties at $1 \%$ level of significance. The model result indicates that as the distance from market center increase by one hour, the probability of adoption of improved soya bean varieties decreases by $27.4 \%$ while intensity of adoption decrease by $153.8 \%$. The possible explanation for this is that farmers who are far away from market centers might face greater transaction and transport costs and lack of information on the availability of the latest released technology provided by extension system. This is in line with previous studies by Yenealem et al. (2013), Berihun et al. (2014) and Debelo (2015) who found that distance to nearest market influence adoption of new technology negatively. According to Yenealem et al. (2013), Berihun et al. (2014) and Debelo (2015) distance to nearest market affect adoption of improved maize varieties in West Harerghe zone, agricultural technologies in southern Tigray, Quncho Tef in Wayu Tuqa District negatively and respectively.

Off farm: participation on off-farm activities positively and significantly related to probability of adoption of improved soya bean varieties at $10 \%$ level of significance, implying that farmers who participated on off-farm activities are more likely adopt improved soya bean varieties than those households who didn't participated on off-farm activities. . As compared to households who did not participated on off farm activities, the probability of adoption of improved soya bean increases by $6.8 \%$ for households who participated on off farm activities. This is in line with previous studies by Olalekan and Simeon (2015) who found that engagement in off farm activities was negatively related to dis-adoption of improved maize varieties.

Livestock (LIVESTOCK): Livestock holding positively and significantly related to probability of adoption and intensity of adoption of improved soya bean varieties at $10 \%$ and $5 \%$ level of significance respectively, implying that farmers with more livestock holding are more likely adopt and devote significant amount of land to improved soya bean varieties than those households with less livestock holding. A household with large livestock holding can obtain more cash income from the sales of animal products. This income in turn helps smallholder farmers to purchase farm inputs. A one unit increase in livestock holding (TLU) increases the the probability of adoption of improved soya bean varieties by $0.3 \%$ while A one unit increase in livestock holding (TLU) increases the intensity of adoption of improved soya bean varieties by $11 \%$. This is consistent with the studies by Solomon et al. (2011), Hassen et al. (2012) and Leake and Adam (2015). According to Leake and Adam, Hassen et al and Solomon et al livestock holding affect intensity of adoption of improved chickpea varieties in Ethiopia, chemical fertilizer technology adoption in North Eastern highlands of Ethiopia and improved wheat variety in northern Ethiopia positively and respectively.

\section{Recommendations}

On the basis of the results of this study, the following recommendations are suggested as to be considered in the future intervention strategies which are aimed at promotion of improved soya bean varieties. 
Sex has a significant positive impact on adoption of improved soya bean varieties. To increase and instigate the likelihood of adopting modern agricultural technologies like improved soya bean by smallholder farmers, policy makers should put emphasis on empowering female headed households to be participants and agents of change by considering a comprehensive and an integrated development of the country where their involvement is pertinent in all endeavors of the country's overall development. From the finding of the study adoption of improved soya bean varieties has a positive impact on farm income; therefore, scaling up and diffusion of improved soya bean varieties in the study area should be broadened.

Education has a significant positive impact on adoption and intensity of adoption of improved soya bean varieties. Hence, strengthening adequate and effective basic educational opportunities to the rural farming households in general and to the study areas in particular is required. In this regard, the regional and local governments need to strengthen the existing provision of formal and informal education through facilitating all necessary materials.

Farm experience increases intensity of adoption of improved soya bean varieties. This indicates that as farm experience get increases the household acquires new information, know the benefits of new technologies and develop confidence to use improved technologies. Thus, concerned bodies need to give emphasis to involve farmers to exercise and use new technologies through demonstration, training and field days. Besides, development agents, local leaders, and other participants should create the room for experience sharing among farmers regarding the importance of improved technologies.

Training on soya bean production was found to be positively and significantly influenced adoption and intensity of adoption of improved soya bean varieties. Hence, concerned bodies should provide adequate and effective training on soya bean production to the rural farming households in general and to the study areas in particular. Thus, systematic arrangements of farmer training should be implemented in order to acquaint farmers with different agricultural technologies. In this regard, N2 Africa and BARC need to focus on training of farmers about improved soya bean varieties.

Distance to nearest market was statistically significant and negatively affected positively and significantly influenced adoption and intensity of adoption of improved soya bean varieties. Hence, concerned bodies need to establish market center for the farmers around their home which increase the probability of adoption of improved soya bean varieties.

The size of livestock owned has a significant positive impact on intensity adoption of improved soya bean varieties. Strengthening the existing livestock production system through providing improved health services, better livestock feed (forage), targeted credit and adopting agro-ecologically based high-yielding breeds and disseminating artificial insemination in the areas improve intensity of adoption of improved soya bean varieties.

\section{References}

Afework Hagos and Lemma Zemedu. 2015. Determinants of improved rice varieties Adoption in Fogera District of Ethiopia. Science, Technology and Arts Research Journal, 4(1): 221-228.

Ajayi, O.C., Franzel, S., Kuntashula, E., \& Kwesiga, F. 2003. Adoption of improved fallow technology for soil fertility management in Zambia: Empirical studies and emerging issues. Agroforestry Systems. 59: 317-326.

Aman Tufa and Tewodros Tefera. 2016. Determinants of improved barley adoption intensity in Malga district of Sidama Zone, Ethiopia. International Journal of Agricultural Economics, 1(3): 78-83.

Assefa Admassie and Gezahegn Ayele. 2010. Adoption of improved technology in Ethiopia. Ethiopian Journal of Economics, 1(5): 155-178.

Becerril, J., \& Abdulai, A. 2009. The impact of Improved Maize Varieties on Poverty in Mexico: A Propensity Score-Approach. World Development 38:1024-1035.

Berihun Kassa, Bihon Kassa and Kibrom Aregawi. 2014. Adoption and impact of agricultural technologies on farm income: evidence from southern Tigray, Northern Ethiopia. International Journal of Food and Agricultural Economics, 2(4): 91-106.

Besley, T., \& Case, A. 1993. Modeling Technology Adoption in Developing Countries. The American Economic Review 83:396-402.

Buraimo, B., Humphreys, B., \& Simmons, R. 2010. Participation and engagement in sport: A double hurdle approach for the United Kingdom (Working Paper). Preston, United Kingdom: University of Central Lancashire.

Carroll, J., McCarthy, S., and Carol, N. 2005. An econometric analysis of charitable donations in the Republic of Ireland. The Economic and Social Review, 36: 229- 249.

Cochran, W. G. 1977. Sampling techniques (3rd ed.). New York: John Wiley \& Sons.

Cragg, J.G. 1971. Some statistical models for limited dependent variables with application to the demand for durable goods. Econometrical, 39(5): 829-844.

CSA (Central Statistical Agency) 2016. Agricultural sample survey 2015/16 (2008E.C): volume v- report on area, production and farm management practice of belg season crops for private peasant holdings. Statistical 
Bulletin, Central Statistical Agency, Addis Ababa, Ethiopia.

Datt, G., and Ravallion, M. 1996. How Important to India's Poor is the Sectoral composition of Growth? World Bank Economic Review 10(1), 1-26.

Debelo Duressa. 2015. Analysis of factors influencing adoption of Quncho Tef: The case of Wayu Tuqa district. International Journal of African and Asian Studies, 12: 2409- 6938.

Degu, Getahun, W. M. Mwangi, Hugo Verkuijl, and Abdishekur Wondimu.2000. An assessment of the adoption of seed and fertilizer packages and the role of credit in smallholder maize production in Sidama and North Omo Zones, Ethiopia. CIMMYT, 2000.

Diederen, P., Hans van, M., Arjan, W., Katarzyna, B. 2003. Innovation adoption in agriculture; Innovators, Early adaptors and laggards, Wageningan University and Research center, the Netherlands, 22p.

Doss, C.R., \& Morris, M. L. 2001. How Does Gender Affect the Adoption of Agricultural Innovations? The Case of Improved Maize Technology in Ghana. Agricultural Policy 25:27-39.

FAO (Food and Agriculture Organization of the United Nations). 2010. Food outlook. Oil Seeds Business Opportunities Ethiopia, 2009; J.H.M. Wijnands, J.Biersteker, E.N. Van Loo.

Feder, L.,R.E.,Just and O.,Zilberman. 1985. Adoption of agricultural innovation in developing countries: A survey, Economic Development and Cultural Change, 32(2): 255- 297.

Foster, A.D and Rosenzweig, M.R .2010. Micro economics of Technology Adoption. Economic Growth Center Yale University center discussion paper No.984 http://www.econ.yale.edu/ egcenter/publications.html

Gemeda, A., Aboma, G. Verkuijl, H., \& Mwangi,W. 2001. Farmers' Maize Seed Systems in Western Oromia, Ethiopia. Mexico, D.F.: International Maize and Wheat Improvement Center (CIMMYT) and Ethiopian Agricultural Research Organization (EARO). p 32.

Greene, W.H. 2000. Econometric analysis, $4^{\text {th }}$ edition. Englewood Cliffs, NJ: Prentice Hall.

Gujarati, D. 2003. Basic econometrics (4 ${ }^{\text {th }}$ edition). New York: McGraw Hill.

Hailegiorgis Biramo. 2010. Export performance of oilseeds and its determinants in Ethiopia. Haramaya University, College of Agriculture and Environmental Science, Department of Agricultural Economics.

Hassen Beshir, Bezabih Emana, Belay Kassa and Jema Haji. 2012. Determinants of chemical fertilizer technology adoption in North Eastern highlands of Ethiopia: the double hurdle approach. Journal of Research in Economics and International Finance, 1(2): 39-49.

Hossain, S., Alamgir, M., and Croach, R. 1992. Patterns and Determinants of Adoption of Farm Practices.Some evidence from Bangladesh. Agric. Systems, 38:1-15.

Ibrahim, M., Florkowski, W.J., \& Kolavalli, S. 2012.The Determinants of Farmer Adoption of Improved Peanut Varieties and Their Impact onFarm Income: Evidence from Northern Ghana.Selected Paper prepared for presentation at the Agricultural and Applied Economics Association Annual Meeting, Seattle, WA, August 12-14, 2012.3.

Kebede, Y, K. Gunjal and G. Coffin. 1990. Adoption on new technologies in Ethiopia agriculture: the case of Tegulet-Bulga district, Shoa province. Agricultural Economics, 4 (1): 27-43.

Leake G.Silassie and Adam Bekele. 2015. Factors determining allocation of land for improved wheat variety by smallholder farmers of northern Ethiopia. Journal of Development and Agricultural Economics, 7(3): 105112.

Maddala, G.S. 1992. Limited dependent and qualitative variables in econometrics. New York: Cambridge University Press.

Martinez-Espineira, R. 2006. A box-cox double-hurdle model of wildlife valuation: The citizen's perspective. Ecological Economics, 1: 192-208.

Mendola, M., 2007. Agricultural Technology Adoption and Poverty Reduction: A propensity Score Analysis for Rural Bangladesh. Food Policy 32:372-393.

Million Tadesse and Belay Kasa. 2004. Determinants of fertilizer use in Gununo area, Ethiopia. Pp. 21-31. In Tesfaye Zegeye, Legesse Dadi and Dawit Alemu (Eds). Proceedings of Agricultural technology evaluation adoption and marketing. Workshop held to discuss results of 1998-2002, august 6-8, 2002.

Moffatt, P. G. 2005. Hurdle models of loan default. Journal of the operational research society, 56(9), 1063-1071.

Morris, M.L., Trip, R., \& Dankyi, A.A. 1999. Adoption and impact of improved maize production technologies. A case study of the Ghana Grains Development Project. Economics Program Paper 99-01.International maize and Wheat Improvement Center (CIMMYT), Mexico.38 pp.

Moti Jaleta, Chilot Yirga, Menale Kassie, Groote. H.D. and Bekele Shiferaw. 2013. Knowledge, adoption and use intensity of improved maize technologies in Ethiopia. Invited paper presented at the 4th International Conference of the African Association of Agricultural Economists, September 22-25, 2013. Hammamet, Tunisia.

Olalekan, A.W and Simeon, B.A. 2015. Discontinued use of improved maize varieties in Osunstate, Nigeria. Journal of Development and Agricultural Economics, 7(3): 85- 91.

Samuel Diro, Efrem Asfaw, Beza Erko and Misganaw Anteneh. 2017. Factors affecting adoption and degree of 
adoption of soya bean in Ilu-Ababora Zone; Southwestern Ethiopia. Agricultural Science Research Journal, 7(1): $15-26$.

Solomon Asfaw and Bekele Shiferaw. 2010. Agricultural technology adoption and rural poverty: Application of Endogenous Switching regression for selected East African countries. Poster Presented at the joint $3^{\text {rd }}$ African Association of Agricultural Economics (AAAE): 19-23.

Solomon Asfaw, Bekele Shiferaw, Franklin Simtowe and Mekbib Gebretsadik Haile. 2011. Agricultural technology adoption, seed access constraints and commercialization in Ethiopia. Journal of Development and Agricultural Economics, 3(9), 436-447.

Storck, H., Bezahih Emana, Berhanu Adnew, A. Borowiecki and Shimelis Wolde Hawariat,S. 1991. Farming systems and farm management practices of smallholders in the Hararge highlands (Vol.II). Farming systems and resource Economics in the tropics. Wisssenschafts, Vauk, Kiel, Germany.

Sunding, D. and David, Z. 2000. Research and technology adoption in a changing agricultural sector. Handbook of Agricultural Economics. University of California at Berkeley. 105p.

Teklewold H., Dadi L.,Yami A. and Dana N. 2006.Transforming village poultry systems into small agro-business ventures: a partnership model for the transfer of livestock technologies in Ethiopia. Livestock Research for Rural Development. 18 (3), Article \#169.

Tiamiyu, S.A., Usman, A. and Ugalahi, U.B. 2014. Adoption of On-farm and Post-harvest Rice Quality Enhancing Technologies in Nigeria. Tropicultura, 32(2): 67- 72.

UNDP (United Nation Development Program). 2013. Towards building resilience and supporting transformation in Ethiopia. Annual Report, 2013. www.et.undp.org. (Accessed on March, 2016).

Uaiene, R.N., Arndt, C., \& Masters, W.A. 2009. Determinants of Agricultural Technology Adoption in Mozambique. Discussion papers No. 67E January 2009 National Directorate of Studies and Policy Analysis Ministry of Planning and Development Republic of Mozambique

Wuletaw Mekuria and Daniel Tadesse. 2015. Determinants affecting adoption of malt-barley technology: Evidence from North Gondar Ethiopia. Journal of Food Security 3(3): 75-81.

Yemane Asmelash. 2014. Determinants of adoption of upland rice varieties in Fogera district, Ethiopia. Journal of Agricultural Extension and Rural Development, 8 (12): 332-338.

Yenealem Kassa, Ranjan S. Kakrippai and Belaineh Legesse. 2013. Determinants of adoption of improved maize varieties for male headed and female headed households in West Harerghe Zone, Ethiopia. International Journal of Economic Behaviour and Organization, 1(4): 33-38.

Yu, B., A. Nin-Pratt, J. Funes, and S. Asrat Gemessa. 2011. Cereal Production and Technology Adoption in Ethiopia. ESSP II Working Paper 31. Addis Ababa, Ethiopia: Ethiopia Strategy Support Program II, International Food Policy Research Institute. 